\title{
A parrhesia como ética/estética da existência em Caim de José Saramago
}

\author{
Parrhesia as ethics/aesthetics of existence in Cain by José Saramago
}

\author{
Alana de Oliveira Freitas El Fahl* \\ Universidade Estadual de Feira de Santana, \\ Feira de Santana, Bahia, Brasil \\ Marcos Fellipe Costa Marques** \\ Universidade Estadual de Feira de Santana, \\ Feira de Santana, Bahia, Brasil
}

Resumo: No último romance do escritor português José Saramago (1922-2010), Caim (2009), o discurso religioso é retomado como tema através de uma releitura paródica de textos bíblicos fundantes da tradição judaico-cristã. No romance, narrador e herói passeiam por cenas bíblicas questionando interpretações sedimentadas na cultura pelas teologias oficiais e dogmas da tradição. As críticas construídas no romance têm como alvo privilegiado os discursos religiosos, sobretudo, a moral criada a partir de tais discursos. Este artigo tem como objetivo demonstrar como, no romance Caim, a parrhesia, o franco falar, funciona como possibilidade ética diante de construções discursivas monológicas dogmáticas e retóricas. Para isso, discutiremos a relação entre o discurso literário de Saramago e o discurso religioso dogmático, destacaremos a função da paródia para apresentar novas versões de discursos já sedimentados na cultura para enfim discutir o conceito de parrhesia em Michel Foucault (1926-1984) e possibilidades interpretativas do romance supracitado a partir desse conceito.

Palavras-chave: Caim. Paródia. Discurso religioso. Parrhesia.

\begin{abstract}
In the last novel by the Portuguese writer José Saramago (1922-2010), Cain (2009), the religious discourse is taken up again as a theme through a parody re-reading of Biblical texts founding the Judeo-Christian tradition. In the novel, narrator and hero stroll through biblical scenes questioning interpretations sedimented in the culture by the official theologies and dogmas of the tradition. The criticisms built in the novel are aimed at religious discourses, especially the moral created from such discourses. This article aims to demonstrate how, in the Cain novel, parrhesia, the frank talk, functions as an ethical possibility in the face of dogmatic and rhetorical monological discursive constructions. To this end, we will discuss the relationship between Saramago's literary discourse and dogmatic religious discourse, we will highlight the function of parody to present new versions of discourses already sedimented in the culture, in order to highlight interpretive possibilities of scenes of the novel from the concept of parrhesia of Michel Foucault (1926-1984) developed in The hermeneutics of the subject (1982).
\end{abstract}

Keywords: Cain. Parody. Religious discourse. Parrhesia

* Professora Titular da Universidade Estadual de Feira de Santana, Doutora em Teorias e Críticas da Literatura e da Cultura, UFBA. E-mail: alanafreitasfahl@gmail.com.

** Mestrado em andamento em Literatura e Diversidade Cultural na Universidade Estadual de Feira de Santana. E-mail: profmfelipe@gmail.com. 


\section{INTRODUÇÃO}

Este estudo faz parte de uma pesquisa de mestrado intitulada Ensaio sobre a subversão: uma leitura de Caim de José Saramago, realizada no âmbito do Programa de Pós-Graduação de Estudos Literários da Universidade Estadual de Feira de Santana. No presente estudo, utilizamos o conceito de parrhesia, desenvolvido pelo filósofo francês Michel Foucault, para tecer uma análise do último romance do escritor português José Saramago, Caim, no qual é destacada uma série de cenas veterotestamentárias que compõe a base mítica da civilização cristã ocidental. Tais cenas são, no romance, deslocadas dos seus espaços de poder, dos lugares sagrados, dos limites das certezas religiosas e dos conceitos teológicos totalizadores para o espaço da ironia e da carnavalização, dessacralizando personagens e discursos, derrubando os muros das certezas e dos dogmas para expor suas mais inquietantes fragilidades e contradições. O romance traz temáticas perseguidas pelo autor durante parte significativa de sua obra - Deus, a humanidade e a religião.

A severa crítica à tradição judaico-cristã é recorrente na obra saramaguiana. Tal crítica chega ao ápice em seus romances O Evangelho Segundo Jesus Cristo (1991) e Caim. Nesse último, objeto deste projeto, é expresso o desejo do humano de matar Deus para superar a realidade moral criada e consolidada sobre esta personagem. Eduardo Lourenço (1994, p.188) afirma, que a ficção do Nobel português é de ordem moral e a situa na linha dos grandes moralistas da ficção portuguesa do século XVII.

Defendemos, sobretudo, que a ênfase saramaguiana dos temas religiosos se dá a partir do diálogo fértil que há entre ética e estética. Esses dois campos só podem ser desmembrados in abstrato. In concreto, eles se entrançam inseparavelmente no tecido ficcional. A ética saramaguiana é uma ética humanista crítica, dirigida aos comportamentos individuais e sociais, como ressalta Said (2007, p. 41-42): “o humanismo é crítica, uma crítica dirigida à situação [...] e que adquire a sua força e relevância pelo seu caráter democrático secular e aberto". Já a estética, toma contornos nietzschianos, apresentando-se como criação de novos modos de ser e de ver o mundo sempre tendo a vida como ponto de partida e de chegada. Como ressalta Rosa Dias, para Nietzsche (2015, p. 239), "embelezar a vida é sair da posição de criatura contemplativa e adquirir os hábitos e os atributos de criador, ser artista de sua própria existência". Dessa forma, entendemos que o encontro entre ética e estética em Saramago é uma das molas propulsoras da sua obra, pois há em suas obras uma série de avaliações éticas que convidam o leitor a recriar formas de ver e estar no mundo colocando sob suspeita as narrativas que nos constroem como sujeitos. Tais provocações e chamados à reinterpretação e recriação das nossas histórias funcionam como fios condutores de grande parte de seus romances.

Ao longo da obra saramaguiana, os comportamentos humanos são desnudados e avaliados, tanto tomando como base nossas construções coletivas, como, por exemplo, nossas instituições; quanto das nossas ações individuais diante dos outros e da vida. Essas avaliações éticas não resultam em fórmulas para um desenvolvimento ético, ou em propostas utópicas prontas de uma sociedade melhor. As avaliações, geralmente desenvolvidas a partir de questionamentos, apontam caminhos, mas, sobretudo, 
convidam o leitor a ser criador dos seus próprios caminhos, a se libertar dos condicionamentos sociais e construir, criar esteticamente, sua própria forma de ver e viver, assumir a condição de autor de sua vida.

Em Caim, o autor avalia especialmente o comportamento da personagem Deus, no entanto, não há uma fuga do humano, nem mesmo do imanente para o transcendente. Na obra saramaguiana, falar sobre Deus é falar sobre o homem, acompanhando a constatação de Feuerbach, quando afirma que:

A consciência de Deus é a consciência que o homem tem de si mesmo[...] Pelo deus conheces o homem e vice-versa pelo homem conheces o seu Deus; ambos são a mesma coisa. O que é Deus para o homem é o seu espírito, a sua alma e o que é para o homem seu espírito, seu coração, isto é também o seu Deus: Deus é a intimidade revelada, o pronunciamento do Eu do homem; a religião é uma revelação solene das preciosidades ocultas do homem, a confissão dos seus mais íntimos pensamentos, a manifestação pública dos seus segredos de amor (FEUERBACH 2007, p. 44).

O lugar de destaque que Saramago coloca a Bíblia acompanha essa perspectiva. A Bíblia é abordada como livro da cultura, que ocupa lugar importante na construção e desenvolvimento da civilização ocidental. Esse lugar de destaque é corroborado por Magalhães, que destaca a tradição judaico-cristã e seu livro sagrado como referenciais para a ética construída no ocidente:

[...] pelo fato de a tradição judaico-cristã participar da construção da civilização ocidental, a Bíblia é um livro de todo ser humano, porque nele se encontram diversas imagens que fabricaram os imaginários das sociedades e suas histórias ainda hoje são referenciais de muitas atitudes e comportamentos éticos (MAGALHÃES, 2000, p.199).

Segundo Magalhães (2000), o discurso bíblico é utilizado tanto para fundamentar a opressão dos poderosos, quanto para animar os pequenos para lutar por liberdade, tanto para fundamentar morais conservadoras, quanto liberais e que ainda hoje determina as grandes discussões e questões da nossa civilização. Como podemos ver no trecho citado:

Suas narrativas se tomaram paradigmas tanto da invasão dos opressores quanto da rebeldia de movimentos emancipadores. Seus códigos de ética se tomaram base do rigor de conservadores e de suporte da moral dos liberais. Suas normas de comportamento influenciam decisivamente relações familiares, sociais e políticas. Podemos dizer. Sem nenhuma dúvida, que a Bíblia é o livro por excelência da civilização ocidental, como nenhum outro conseguiu se tornar, mesmo levando em conta a criatividade e a vastidão literária dos países ocidentais [...] nele reside a seriedade de toda uma civilização, os fundamentos éticos e religiosos de diferentes culturas e a reserva de temas que passaram a determinar a maior parte dos grandes debates que ainda hoje continuamos a discutir. (MAGALHÃES, 2000, p.97, grifo nosso).

Diante de tais observações, acreditamos que, em Caim, Saramago nos oferece a mesma experiência mencionada pelo escritor francês Marcel Proust, quando em seu último livro relata que: "seria inexato dizer que me preocupavam os que o leriam, os leitores. Porque, como já demonstrei, não seriam meus leitores, mas leitores de si 
mesmos" (PROUST, 2004, p. 280). Em seu último livro, Saramago fornece a seu leitor meios de se lerem quando nos coloca em diálogo com os mitos fundantes do sujeito moderno ocidental, com as narrativas que formam o que há de mais íntimo em nós.

Neste artigo, tentaremos demonstrar que a parrhesia, o "franco falar" ou a "coragem de dizer a verdade" é um conceito que ilumina a produção literária aqui abordada, pois desafia o sujeito a ler a si mesmos, desconstruir os discursos de poder que o compõe, buscando sua própria verdade para de forma ética dialogar com o mundo.

\section{A LINGUAGEM RELIGIOSA E A RELIGIÃO COMO LINGUAGEM}

A religião cristã é abordada como uma criação humana, que organiza e dá sentido ao mundo. Para Rubem Alves, a religião é uma linguagem, "um jeito de falar sobre o mundo" (ALVES, 1999, p. 5). Um discurso sobre a realidade que, como outros discursos, povoam a arena de lutas por poder e por status de verdade. Explorando a assertiva de Wittgenstein quando este afirma que "os limites da minha linguagem denotam os limites do meu mundo" (apud ALVES, 1999, p.17), podemos inferir que a linguagem que limita o mundo ao que somos capazes de dar sentido é a mesma que amplia o mundo e que cria novos "mundos" através da criação de novas formas de dizer a realidade. Se entendermos o discurso religioso como representação da realidade, como organização e significação do caos do real, podemos afirmar que Saramago cria um espaço/tempo literário em diálogo constante com essa realidade criada pelo discurso religioso. Esse espaço/tempo literário tem uma ética que tensiona e questiona a ética e a moral da religiosidade cristã vigente. Deste modo, parte fundamental do projeto literário de Saramago pode ser resumido como uma releitura crítica-criativa da religiosidade cristã ocidental a partir de uma perspectiva ética humanista.

Ao abordar a religião não apenas como instituição, mas como linguagem, o autor português amplia as possiblidades de diálogo entre esta e seus romances-ensaios, entre os discursos da religião e os discursos da literatura. Abordar o texto saramaguiano limitandose a pensar a religião nela representada recorrendo às sociologias da religião ou as ciências da religião que as analisa sob as perspectivas das instituições religiosas ou a partir da análise dos dogmas e ideias que lançam no mundo é perder o que há de mais importante nas abordagens religiosas do autor português: o diálogo entre as linguagens "imaginárias" da religião e da literatura. Abordar a religião como imaginação humana não é diminuí-la nem a menosprezar, longe disso. Após afirmar que "entidades religiosas são entidades imaginárias", Rubem Alves (2003) ressalta:

Não, não estou dizendo que a religião é apenas imaginação, apenas fantasia. Estou sugerindo que ela tem o poder, o amor e a dignidade do imaginário. Mas, para elucidar declaração tão estapafúrdia, teríamos de dar um passo atrás, até lá onde a cultura nasceu e continua a nascer. Por que razões os homens fizeram flautas, inventaram danças, escreveram poemas, puseram flores nos seus cabelos e colares nos seus pescoços, construíram casas, pintaram-nas de cores alegres puseram quadros nas paredes? Imaginemos que estes homens tivessem sido totalmente objetivos, totalmente dominados pelos fatos, totalmente verdadeiros — sim, verdadeiros! - poderiam eles ter inventado coisas? Onde estava a flauta antes de ser inventada? E o jardim? E as danças? E os quadros? Ausentes. Inexistentes. Nenhum 
conhecimento poderia jamais arrancá-los da natureza. Foi necessário que a imaginação ficasse grávida para que o mundo da cultura nascesse (ALVES, 2003, p. 31).

Engana-se quem acredita que os discursos religiosos por se ocuparem de coisas "imaginárias" ou de "outro mundo" pouco interferem no cotidiano das sociedades contemporâneas. Os discursos religiosos, assim como seus textos, servem de âncora tanto para práticas violentas opressivas, quanto para práticas libertadoras. Mesmo após tais considerações podem surgir as perguntas: Por que falar de Deus hoje? Ainda há relevância? Por que um ateu se ocupa do tema religioso e se ocupa de paródias bíblicas que demandaram horas de pesquisa bíblica, horas debruçado sobre um texto que é sagrado para muitos, mas que não representa isso para ele? Como disse o filósofo alemão, "A crítica da religião é o pressuposto de toda crítica". (MARX, 2008, p. 5). Sendo assim, podemos perceber na leitura dos romances saramaguianos que o escritor lusitano leva a crítica à religião como parte importante da sua crítica ao modo de vida da sociedade ocidental.

Religiões portam discursos poderosos, com imenso poder criativo, logo, quando instrumentalizados para manter ou corroborar com a manutenção do poder instituído ou com a manutenção da violência eles tem grande valia. Saramago aborda o discurso religioso como aborda o discurso histórico - como discurso que constrói o presente. As composições saramaguianas não buscam negar a religião ou a espiritualidade, mas sim questioná-las, especialmente as religiões dogmáticas e as espiritualidades que negam o humano e a vida. Como afirma Martins, Saramago desenvolve em seus romances uma busca própria pelo sagrado: "a espiritualidade atravessa os romances ao ritmo da dúvida e do desassossego de um autor em busca do sentido para o humano e sobretudo, para as construções humanas do divino. (MARTINS, 2014, p.19).

Em Caim, o texto bíblico é a base para a composição ficcional. No entanto, Saramago cria um enredo paralelo ao bíblico, em que o herói, condenado à errância, passeia por inúmeros episódios bíblicos. Se em O Evangelho Segundo Jesus Cristo, há uma releitura da história da vida de Jesus e da personagem Deus, em Caim há releituras das principais cenas do Antigo Testamento: "a criação"; "o pecado original”, como chamado pela tradição; o sacrifício de Isaac, a Torre de Babel; a destruição de Sodoma e Gomorra; a estátua de sal, o bezerro de ouro, a arca de Noé, entre outras. Apesar da quantidade de cenas que compõem o enredo, a discussão sobre a personagem Deus torna-se ainda mais central nesse último romance. A forma utilizada por Saramago para trazer o texto bíblico ao palco de sua realização literária foi a paródia. A fim de iluminar como funciona a paródia, Gerard Genette faz uma análise etimológica da palavra:

Primeiramente, a etimologia: ôdè, que é o canto; para, "ao longo de", "ao lado"; parôdein, daí parôdia, que seria (portanto) o fato de cantar ao lado, de cantar fora do tom, ou numa outra voz, em contracanto - em contraponto -, ou ainda, cantar num outro tom: deformar, portanto, ou transpor uma melodia (GENETTE, 2010, p. 26-27).

Assim sendo, podemos compreender a paródia como uma soma intrusa, algo a mais é adicionado ao canto de forma que o modifique, mas não é um novo canto que se inicia quando o outro termina, é um canto em contraponto, ou em outro tom, cantado 
juntamente com o primeiro. Quando empregada a partir de um texto, como o analisado aqui, a paródia pode ser descrita, conforme Kothe, como,

[...] um texto que contém outro texto em si, do qual ela é uma negação, uma rejeição e uma alternativa. Ela geralmente diz que o outro texto deixou de dizer e ela insiste no fato de não ter sido dito. A paródia é um texto duplo, pois contém o texto parodiado e, ao mesmo tempo, a negação dele. Ela é, portanto, a síntese de uma contradição, dando prioridade para a antítese, em detrimento da tese proposta pelo texto parodiado. [...] Sempre surge como resposta à institucionalização sacralizadora de um texto (KOTHE, 1980, p. 98).

Os romances Saramaguianos destacados são paródias de textos considerados por muitos como sagrados. Logo, são textos "profanos" que trazem em si, textos "sagrados". O primeiro efeito que Saramago busca no leitor é provocá-lo a perceber que os textos bíblicos são versões de acontecimentos. Vale ressaltar que, como já dito, os acontecimentos, para o autor, são acontecimentos narrativos. Apenas versões e não a revelação da Verdade divina, como algumas tradições religiosas atestam. Em seus romances, isso é tratado com humor e ironia, quando o narrador tenta convencer o leitor que seu relato é uma versão tão verdadeira ou até mais que as versões canônicas. $\mathrm{O}$ narrador de $O$ Evangelho Segundo Jesus Cristo tenta convencer o leitor citando os nomes dos anciãos da sinagoga que foram à casa de José investigar o suposto mistério do pedinte e da terra brilhante:

Saíram pois os emissários, com José à frente, a indicar o caminho, e eram eles Abiatar, Dotaim e Zaquias, nomes que aqui se deixam registados para estorvar qualquer suspeita de fraude histórica que possa, acaso, perdurar no espírito de todas aquelas pessoas que destes factos e suas versões tenham obtido conhecimento através doutras fontes, porventura mais acreditadas pela tradição, mas não por isso mais autênticas. (SARAMAGO, 1991, p.37).

Apesar do tom humorado das narrativas, especialmente em Caim, os textos trazem análises sérias e apontam supostas contradições internas das narrativas bíblicas, corroborando com a assertiva de Bakhtin quando afirma que "na paródia, o "discurso se converte em palco de luta entre duas vozes" (2013, p. 221). Ao proceder releituras de episódios bíblicos, Saramago não compõe um discurso monológico, como os discursos religiosos dogmáticos que reduzem as possibilidades interpretativas do texto aos limites de suas "verdades" estabelecidas, muito menos tenta minimizar a importância dos mitos fundadores do mundo ocidental, mas questiona-os e coloca os sentidos e os significados desses em disputa. Frente aos dogmas e às verdades sedimentadas pela tradição Saramago toma uma posição firme, como o próprio profere, somos, desde sempre, "simples repetidores de histórias antigas, [...] passando continuamente da credulidade mais ingénua ao cepticismo mais resoluto" (SARAMAGO, 2009, p. 102).

Para Saramago, repetir histórias, faz parte do que somos, no entanto, repeti-las não aponta para a fixação do passado, mas sim para a possibilidade de transformação do presente, pois questionar nossas histórias é também questionar quem somos. Dessa forma, como ressalta Aragão, o método paródico pretende questionar os valores do presente construídos com base em interpretações dos textos do passado: 
A paródia [...] é o lugar onde se manifesta a dúvida sobre os valores tradicionais. O olhar profundo que a caracteriza aponta para a possibilidade de transformação do presente, seja pela crítica à sociedade atual, às tradições, seja pela abertura que permite a passagem a novas possibilidades de ser e de pensar (ARAGÃO, 1980, p. 21).

Saramago mantém parte da história bíblica, dando uma impressão de fidelidade ao texto, e usa os silêncios para tecer sua própria versão. Com o uso dos apócrifos, há um enriquecimento do texto e também a repetição de uma tendência frequente das narrativas saramaguianas que é dar voz às personagens ou perspectivas esquecidas ou marginalizadas pelas leituras oficiais.

\section{A PARRHESIA COMO ÉTICA/ESTÉTICA DA EXISTENCIA: O SACRIFÍCIO DE ISAAC}

Não foi por acaso que o autor colocou Caim, em sua primeira viagem pelo tempo, diante da cena do sacrifício de Isaac. Essa cena é de importância vital para compreendermos como Saramago dá início, juntamente com sua personagem Caim, a uma viagem por tempos/espaços discursivos que pretende expor e questionar os discursos que marcam a cultura cristã ocidental.

Apontaremos dois aspectos que justificam a escolha desta, entre inúmeras do Antigo Testamento, para ser a primeira cena da homérica jornada de Caim pelos episódios veterotestamentários, destacados pelo autor no romance. O primeiro é a força representativa que contém essa cena para marcar a origem da fé em Yahweh, o "Deus de Israel". Enquanto a narrativa da criação do mundo marca a origem de todas as coisas, a saga de Abraão marca a origem da fé judaica. Assim visitar essa cena e colocá-la em questão é também questionar a fé em Deus, desde sua origem. O outro aspecto é o caráter ético das questões que movimentam os diálogos com as cenas veterotestamentárias. A abordagem realizada pelo autor, sobretudo através da personagem Caim e das intrusas opiniões do narrador tem, especialmente, a finalidade de questionar e reprovar a moral contida nos episódios bíblicos. A escolha da cena do sacrifício de Isaac é justificada pela sua abordagem emblemática da moral religiosa questionada por Saramago. Por conseguinte, tentaremos, nesta análise, enfatizar as questões éticas tocadas pelo texto e a partir da recusa à moral representada na cena, indicar possibilidades de caminhos éticos para superá-la.

O episódio bíblico é movido pela necessidade de compor a figura do lendário fundador da nação de Israel, Abraão. Abraão, segundo o texto bíblico, recebeu uma promessa de Deus, que seria o Pai de uma grande nação, tal promessa o colocou em movimento. Seguindo instruções de Deus, deslocou-se com seu clã até a terra de Canaã.

Abraão já tinha setenta e cinco anos quando recebeu tal promessa, mesmo assim, passaram-se, ainda, vinte e cinco anos sem que sua esposa Sara lhe desse um filho. Até que, já na velhice, com cem anos e Sara com noventa, nasce Isaac, o "filho da promessa". A narrativa do sacrifício ocorre como uma prova divina, que consistia em Abraão oferecer seu filho a Deus como sacrifício. A riqueza literária da narrativa está no dilema que é gerado: Abraão, ou obedece a Deus e mata seu próprio filho, ou poupa seu filho e 
desobedece a seu Deus. Por escolher obedecer a ordem, Abraão é lembrado e aclamado como um herói, herói da fé, "Pai da fé".

Apesar de ser conhecida e reconhecida por três das maiores religiões mundiais, Cristianismo, Judaísmo e Islamismo, que consideram Abraão como seu fundador, a narrativa causa, até hoje, espanto. Deus pediu a um pai, já velho, que matasse o próprio filho e este obedeceu. Quais as implicações disso para as religiões que tem essa narrativa como parte de sua origem? Como reler esta cena bíblica a partir de uma perspectiva humanista?

Devido a sua riqueza literária e ao espanto que a saga causa, esta é talvez a narrativa mais visitada por críticos e pensadores de todas as épocas. Como por exemplo, Hegel e Freud, que consideram o Deus do episódio como uma projeção do inconsciente de Abraão, "a imagem da própria natureza de Abraão"; Proust e Thomas Mann que reescrevem a saga, demitologizando-a (COUFFIGNAL, 2005, p. 5-6), ou até Auerbach (2012), que a usa como exemplo formal característico do estilo bíblico.

Um dos mais conhecidos e representativos ensaios sobre a narrativa talvez seja Temor e Tremor (1843), do filósofo dinamarquês Sorem Kierkegaard. Neste, o autor destaca de modo recorrente o paradoxo que se manifesta no mito: Deus exige o crime e a tentação consiste em agir eticamente. $\mathrm{O}$ absurdo se dá em ter que decidir cumprir uma exigência moral universal, ou cumprir uma exigência do próprio “Absoluto". (KIERKEGAARD, 1979).

Alguns dos trechos mais belos da obra do dinamarquês se encontra no início do texto nas quatro paráfrases da narrativa bíblica. Na última, ele narra de forma emocionante a perspectiva de Isaac no momento do sacrifício:

Era de manhãzinha. Tudo estava pronto para a partida em casa de Abraão. Despediu-se de Sara, e Eliezer, o fiel servidor, seguiu-o pelo atalho até o momento em que Abraão lhe ordenou o regresso. Depois, em completa concordância, Abraão e Isaac caminharam juntos até a montanha de Morija. Cheio de paz e doçura, Abraão fez os preparativos do sacrifício, mas, quando se voltou para puxar da faca, viu Isaac que a mão esquerda do pai se crispava de desespero, que um arrepio lhe sacudia o corpo e, contudo, Abraão puxou a faca. Regressaram então a casa. Sara precipitou-se ao encontro de ambos. Isaac, porém, já não tinha fé. Nunca de tal coisa se falou no mundo, nem Isaac disse a alguém aquilo que presenciara, nem Abraão suspeitou de que alguém o vira (KIERKEGAARD, 1979, p. 199).

O narrador saramaguiano convida o leitor a olhar para esta cena sem adornos teológicos, ou significados já sedimentados na tradição cultural, como se estivesse diante do fato pela primeira vez. Sua estratégia é deslocar o texto do ambiente sagrado para o espaço prosaico. O tom do texto é de repulsa às atitudes de Deus e de Abraão.

O leitor leu bem, o senhor ordenou a abraão que lhe sacrificasse o próprio filho, com a maior simplicidade o fez, como quem pede um copo de água quando tem sede, o que significa que era costume seu, e muito arraigado. O lógico, o natural, o simplesmente humano seria que abraão tivesse mandado o senhor à merda, mas não foi assim. (SARAMAGO, 2009, p. 79).

A indignação do narrador diante da atitude de Abraão é evidente, mas o que gostaríamos de destacar é que ele cobra uma resposta verbal de Abraão. Ele não sugere apenas que Abraão deveria desobedecer a ordem, mas que deveria "mandar Deus à 
merda". Diante de discursos que fundam violências ou que exigem violências como respostas, não é suficiente a recusa, a resposta verbal é um imperativo ético. Nesse ínterim, podemos concluir que a atitude de Abraão foi ilógica e desumana? Infelizmente não. $\mathrm{O}$ que se percebe no texto é que tal atitude segue outra lógica, vale ressaltar, muito presente em nossa realidade social, que é construída por um discurso religioso desumanizante, mas perfeitamente humano.

Saramago compõe um Abraão fraco, moral e fisicamente, um idoso que se vê pressionado a atender a ordem divina. Apesar da dureza das palavras de Caim, o peso da crítica do autor não recai sobre Abraão, mas sobre o discurso que referenda tal narrativa como modelo de fé. Sua releitura paródica da cena do sacrifício faz-nos perceber que o discurso religioso dogmático tem o poder de negar à pessoa que o adere a possibilidade de lançar ao mundo seu próprio discurso, de ouvir e agir de acordo com sua própria vontade, pois, o impele a assumir discursos de outros, tidos como discursos de Deus. Uma das principais características do discurso religioso é ser considerado como "palavra de Deus" como afirma Orlandi no trecho abaixo, que traz a caracterização desse discurso:

Partindo, então, da caracterização do discurso religioso como aquele em que fala a voz de Deus, começaria por dizer que, no discurso religioso, há um desnivelamento fundamental na relação entre locutor e ouvinte: o locutor é do plano espiritual (o Sujeito, Deus) e o ouvinte é do plano temporal (os sujeitos, os homens). Isto é, locutor e ouvinte pertencem a duas ordens de mundo totalmente diferentes c afetadas por um valor hierárquico, por uma desigualdade em sua relação: o mundo espiritual domina o temporal. O locutor é Deus, logo, de acordo com a crença, imortal, eterno, infalível, infinito e todo-poderoso; os ouvintes são humanos, logo, mortais, efêmeros falíveis, finitos, dotados de poder relativo. $\mathrm{Na}$ desigualdade, Deus domina os homens (ORLANDI, 1987, p. 243).

O discurso religioso ensina que a ordem de Deus deve ser obedecida sem questionamentos, pois a palavra de Deus é absoluta, não há um interlocutor à sua altura, para se dar um diálogo. Quando Deus exige, cabe, apenas, obedecer. A falta de franqueza de Abraão é denunciada no início da descrição da cena. Quando a personagem Abraão decide assumir para si o projeto e o discurso de Deus, ele perde a capacidade de olhar nos olhos do seu filho e dizer a verdade. Assim como, perde a capacidade de assumir suas verdadeiras intenções.

Ó pai, chamou o moço, e logo uma outra voz, de adulto de certa idade, perguntou, Que queres tu, isaac, Levamos aqui o fogo e a lenha, mas onde está a vítima para o sacrifício, e o pai respondeu, O senhor há-de prover, o senhor há-de encontrar a vítima para o sacrifício. E continuaram a subir a encosta. Ora, enquanto sobem e não sobem, convém saber como isto começou para comprovar uma vez mais que o senhor não é pessoa em quem se possa confiar. Há uns três dias, não mais tarde, tinha ele dito a abraão, pai do rapazito que carrega às costas o molho de lenha, Leva contigo o teu único filho, isaac, a quem tanto queres, vai à região do monte mória e oferece-o em sacrifício a mim sobre um dos montes que eu te indicar. (SARAMAGO, 2009, p. 78-79).

Os valores destacados na cena são repetidos nas ações de Abraão e nas palavras do narrador: "Deus não é confiável: “o senhor não é pessoa em quem se possa confiar"; Abraão é um mentiroso: "além de tão filho da puta como o senhor, abraão era um 
refinado mentiroso, pronto a enganar qualquer um com sua língua bífida" (SARAMAGO, 2009, p. 79); Abraão e Deus são pais assassinos que não amam seus filhos: "Que vai você fazer, velho malvado, matar o seu próprio filho, queimá-lo, é outra vez a mesma história, começa-se por um cordeiro e acaba por assassinar aquele a quem mais se deveria amar." (SARAMAGO, 2009, p.80); Deus enlouquece as pessoas: "Não era eu quem estava ali, em meu perfeito juízo nunca o faria, Queres dizer que o senhor enlouquece as pessoas, perguntou isaac, Sim, muitas vezes, quase sempre, respondeu abraão" (SARAMAGO, 2009, p.82).

Saramago denuncia a moral cristã, expondo a falta de franqueza do "Pai da fé" com o próprio filho, quando tenta matá-lo sem, ao menos, dar-lhe a chance de saber o porquê, ou a chance de discordar e lutar pela vida. O discurso religioso, assumido como voz de Deus tem implicações, não apenas àqueles que pactuaram com Deus ou com a religião, aos que creem ou aos que acreditam, mas também aos que estão próximos desses. $\mathrm{O}$ comportamento daqueles que assumem como seus os discursos da religião pode chegar até o limite da violência que é tirar a vida do outro.

O filósofo Michel Foucault, em suas últimas pesquisas, debruçou-se sobre uma ética que pode nos ajudar a compreender as questões saramaguianas levantadas no texto. A partir do "cuidado de si" podemos ser capazes de criar a nós mesmos resistindo aos discursos que nos condicionam e que constroem nossa subjetividade. Essa ética/estética não é uma novidade no mundo, é perseguida desde a Antiguidade clássica passando por uma série de mudanças importantes as quais a fizeram passar de uma espécie de ética individual para uma ética das relações, relações de franqueza com o outro, que é uma relação ética consigo mesmo, do dizer verdadeiro, que transborda para as relações sociais - a parrhesía.

[...] através desse desenvolvimento da prática de si, através do fato de que a prática de si torna-se uma espécie de relação social [...] desenvolve-se creio, algo muito novo e importante, que é uma nova ética, não tanto da linguagem ou do discurso em geral, mas da relação verbal com o Outro. E é essa nova ética da relação verbal com o outro que está designada na noção fundamental de parrhesía. A parrhesia traduzida em geral por "franqueza", é uma regra de jogo, um princípio de comportamento verbal que devemos ter na prática da direção de consciência. (FOUCAULT, 2014, p.148).

Essa regra mencionada está para além de uma mera prestação de contas com o outro porque é gerado pelo princípio de transformação de si e do outro a partir do dizer verdadeiro, redundando em uma relação de franqueza e abertura consigo e com o outro com o qual se relaciona.

[...] A parrhesía é uma qualidade, ou melhor, uma técnica utilizada na relação entre médico e doente, entre mestre e discípulo: é aquela liberdade de jogo, se quisermos, que faz com que, no campo dos conhecimentos verdadeiros, possamos utilizar aquele que é pertinente para a transformação, a modificação, a melhoria do sujeito (FOUCAULT, 2014, p.216).

A ética proposta por Foucault (2014), a ética do franco falar, pode ser melhor compreendida quando consideramos que em suas origens ela era usada entre médicos e doentes. A palavra do médico, conhecedor da natureza, devia ser franca, pois dizer ao 
doente as verdades da natureza poderiam mudar o modo de ser do doente, levá-lo a escolher formas mais saudáveis de vida que o trouxessem a cura.

O falar franco nem sempre acontece sem conflitos, pelo contrário, o correr riscos está implícito como possibilidade. Nesse ínterim, a parrbesía acontece de maneira espontânea, uma ação verbal decidida livremente que transforma não só quem fala, mas também seu interlocutor.

Em Caim, as personagens que mais se aproximam do falar franco são as personagens marginalizadas pela história: Eva, Lilith, Caim, a esposa de Job. Nas margens dos espaços de poder há mais possibilidades de ações éticas. Todos eles falam ao outro não a partir de convenções ou discursos prontos, mas a partir de si mesmo, de suas vontades e necessidades buscando, no falar, verdades que os libertem e que também libertem o outro. Também foram construídas personagens que apenas repetiam um grande discurso, o discurso de Deus, com falas retóricas, discursos prontos que expressavam algo que não estava neles, expressavam o discurso de um só, o discurso de Deus. Na cena do sacrifício de Isaac essas personagens são representadas pelo anjo.

[...] caim não é nenhum anjo, anjo é este que acabou de pousar com um grande ruído de asas e que começou a declamar como um actor que tivesse ouvido finalmente a sua deixa, Não levantes a mão contra o menino, não lhe faças nenhum mal, pois já vejo que és obediente ao senhor, disposto, por amor dele, a não poupar nem sequer o teu filho único, Chegas tarde, disse caim, se isaac não está morto foi porque eu o impedi (SARAMAGO, 2009, p.80).

O anjo, assim como outras personagens do romance, figura como mero repetidor dos "desígnios" divinos. Ainda podemos ver na cena que o tom cômico com o qual Saramago traz seu desfecho, quando indica que a causa do atraso da criatura celestial foi "um problema mecânico na asa direita [que] não sincronizava com a esquerda" (SARAMAGO, 2009, p.80) revela algo importante que acompanha o texto desde o início: o texto bíblico, que para muitos é a revelação da "palavra de Deus", não deve ser levado tão a sério.

A recusa saramaguiana pela ética cristã do discurso religioso aponta para a adoção de uma nova ética, não uma ética universal, também monológica instituída por alguns para todos, mas uma ética que passa pela criação e pelo cuidado de si, que nasce da opção individual e passa para as relações sociais, a ética do franco falar. A coragem de dizer a verdade mesmo correndo riscos. Comparando duas figuras lendárias arquétipos do ocidente poderíamos dizer que o risco de Abraão era perder a promessa de Deus enquanto o risco de Sócrates, o filósofo, quando foi acusado de subverter crenças e costumes de Atenas e corromper a juventude, era a própria morte. O segundo escolheu dizer a sua verdade, o primeiro não, mas os dois morreram como heróis, e suas vozes reverberam até hoje.

O romance de Saramago cumpre uma dupla função, colocar no mundo uma voz franca, apresentando um retrato do tempo presente sem pesar as consequências e uma voz criativa que liberta, pelo jogo da palavra franca, a si e aos outros. É bom lembrar Bakhtin (2013) quando nos faz perceber que a voz de cada sujeito é resultado do encontro de inúmeras vozes, mas é única e irrepetível. Cada enunciado é irrepetível, pois mesmo se 
uma frase for repetida por outra pessoa ou até pelo mesmo sujeito ela estará em um novo contexto, em um novo momento e em diálogo com novas vozes o que trará novos sentidos, logo um novo enunciado. Dito isto, cada pessoa ocupa uma posição diferente no mundo, dialoga com um conjunto de vozes diferentes e produzirá enunciados únicos. Isso torna todos e cada um responsáveis pelo que dizem e pelo que não dizem, pois quando diante de um contexto, o sujeito se recusa a dizer, ninguém poderá dizer do seu lugar. Assim, ética do falar franco é desafiadora e libertadora, pois o mundo precisa de novas palavras, das nossas palavras enquanto sujeitos e de palavras que ousem criar novos sujeitos nos libertando dos condicionamentos e novos mundos de sentido.

\section{REFERÊNCIAS}

ALVES, Rubem. O que é religião? 5. ed. São Paulo: Edições Loyola, 2003.

ALVES, Rubem. O suspiro dos oprimidos. 4. ed. São Paulo: Paulos, 1999.

AUERBACH, Erich. A cicatriz de Ulisses. In: AUERBACH, Erich. Mimesis: a representação da realidade na literatura ocidental. $4^{a}$ ed. São Paulo: Perspectiva, 2002.

BAKHTIN, Mikhail. Problemas da poética de Dostoiévski. 5. ed. Rio de Janeiro: Forense Universitária, 2013.

COUfFIGNAL, Robert. Abraão [verbete]. In: BRUNEL, Pierre. Dicionário de mitos literários. 4. ed. Tradução de Carlos Sussekind. Rio de janeiro: José Olympio, 2005. p. 3-8.

DIAS, Rosa M. Arte e vida no pensamento de Nietzsche. Cadernos Nietzssche. São Paulo, n.36, v. 1, 2015. p. 227-244. Disponível em: http://www.scielo.br/pdf/cniet/v36n1/2316-8242-cniet-36-01-00227.pdf. Acesso em: 06 mar. 2017.

FEUERBACH, Ludwig. A essência do cristianismo. Tradução de José da Silva Brandão. Petrópolis: Vozes, 2007.

FOUCAULT. Michel. A bermenêutica do sujeito. São Paulo: Martins Fontes, 2014.

GENETTTE, Gérard. Palimpsestos: a literatura de segunda mão.Tradução de Cibele Braga, et. al. Belo Horizonte: Edições Viva Voz, 2010.

KIERKEGAARD, Soren. Temor e Tremor. In: Diário de um sedutor; Temor e tremor; O desespero humano. Tradução de Carlos Grifo, José Marinho, Adolfo Monteiro. São Paulo: Abril Cultura, 1979. (Coleção Os pensadores). 
KOTHE, Flávio R. Paródia e Cia. Revista Tempo Brasileiro, n. 62. Rio de Janeiro: Tempo Brasileiro, jul-set 1980. p.97-111.

LOURENÇO, Eduardo. O canto do signo: existência e literatura (1957-1993). Lisboa: Editorial Presença, 1994.

MAGALHÃES, Antonio. Deus no espelho das palavras: teologia e literatura em diálogo. São Paulo: Paulinas, 2000.

MARTINS, Manuel F. A espiritualidade clandestina de José Saramago. Lisboa: Fundação José Saramago, 2014.

MARX, Karl. Para a crítica da filosofia do direito de Hegel. Tradução de Artur Morão. Covilhã, Universidade da Beira Interior, 2008. Disponível em: http://www.lusosofia.net/textos/marx_karl_para_a_critica_da_filosofia_do_direito_de _hegel.pdf. Acesso em: 03 mar. 2017.

ORLANDI, Eni. A linguagem e seu funcionamento: as formas do discurso. $2^{\mathrm{a}}$ ed. Campinas: Pontes, 1987.

PROUST, Marcel. Em busca do tempo perdido. Tradução Mario Quintana. Vol. 1 - No caminho de Swann. São Paulo: Globo, 2006.

SAID, Edward W. Humanismo e crítica democrática. Tradução de Rosaura Eichenberg. São Paulo: Companhia das Letras, 2007.

SARAMAGO, José. Caim. São Paulo: Companhia da Letras, 2009.

SARAMAGO, José. O Evangelho segundo Jesus Cristo. São Paulo: Companhia da Letras, 1991.

Recebido em: 06/03/217 